\title{
ANALYSIS OF THE INTERNAL AUDIT SUBDIVISION ACTIVITY IN THE CORPORATE SECTOR OF THE REPUBLIC OF MOLDOVA
}

\author{
Elena PETREANU1, PhD Student, \\ State University of Moldova
}

\author{
DOI: https://doi.org/10.36004/nier.es.2020.2-07 \\ JEL Classification: D29, F02, F23, M42, 032 \\ UDC: 657.6(478)
}

\section{ABSTRACT}

The actuality of the topic results from the importance of internal audit for owners, potential investors and creditors, as well as from the significance of internal audit as a basic element in corporate governance. At the present moment, there are no studies on the current situation and the role of internal audit in the country's corporate sector. Therefore, the author intended to perform the analysis of the internal audit subdivisions activity in the nominated sector. For this, the relevant research directions have been established, the purpose of which is to study the qualitative characteristics of the internal audit subdivisions. The author has conducted a qualitative study, through a semi-structured interview, and the information analyzed represents the October-December 2019 period. The main results of the study show that the basic functional tasks of an internal audit are the classic tasks, such as safety assessment and the effectiveness of internal control; monitoring the process of liquidating the weaknesses of the internal control system; developing recommendations for improving the internal control system. Failure to comply with the provisions of ISPPIA has been observed. The factors that most influence the activity of the internal audit subdivisions are their insufficient provision with employees and the duration of obtaining the necessary information. It was discovered that independent external evaluations are not performed and planned in the analyzed economic entities, which proves the non-compliance with ISPPIA, due to the lack of need for such an evaluation and the relatively short period of activity of internal audit subdivisions.

Keywords: internal audit, corporate sector, qualitative characteristics, internal audit subdivision, research questionnaires, audit study.

Actualitatea temei rezultă din importanța auditului intern pentru proprietari, potențialii investitori și creditori, de asemenea din semnificația auditului intern în calitatea sa de element de bază în guvernanța corporativă. Autorul a constatat că la momentul de față lipsesc studii vizând situația actuală și rolul auditului intern în sectorul corporativ al țării. De aceea, autorul și-a propus să efectueze analiza activității subdiviziunilor de audit intern din sectorul nominalizat. Pentru aceasta au fost stabilite directiile de cercetare relevante, una dintre care reprezintă studierea caracteristicilor calitative a subdiviziunilor de audit intern. In acest context, scopul cercetării constă în examinarea caracteristicilor calitative ale subdiviziunilor de audit intern din sectorul corporativ al Republicii Moldova. Pentru realizarea acestui scop de către autor a fost utilizată tehnica sondajului, fiind elaborate chestionare corespunzătoare domeniului de cercetare, care ulterior au fost transmise conducătorilor subdiviziunilor de audit intern din sectorul corporativ prin intermediul poștei electronice. Informațiile cuprinse în chestionare reprezintă perioada anului 2019. Rezultatele de bază ale studiului arată că sarcinile funcționale de bază ale auditului intern sunt sarcini clasice, cum ar fi evaluarea siguranței și eficacității controlului intern; monitorizarea procesului de lichidare a punctelor slabe ale sistemului de control intern; elaborarea de recomandări pentru îmbunătătirea sistemului de control intern. Sa observat nerespectarea prevederilor ISPPIA. Factorii care influențează cel mai mult activitatea subdiviziunilor de audit intern sunt asigurarea insuficientă a acestora cu angajați și durata de obținere a informațiilor necesare. S-a identificat că în entitățile economice analizate nu se efectuează și nu sunt planificate evaluări externe independente, ceea ce dovedește nerespectarea ISPPIA, din cauza lipsei necesității unei astfel de evaluări și a perioadei relativ scurte de activitate a subdiviziunilor de audit intern.

Cuvinte-cheie: audit intern, sector corporativ, caracteristici calitative, subdiviziune de audit intern, chestionare de cercetare, studiu în audit.

${ }^{1}$ ID ORCID 0000-0001-7024-3081, $\bowtie$ e-mail: epetreanu@mail.ru

December No. 2/2020 
Актуальность темы обусловлена важностью внутреннего аудита для владельцев, потенциальных инвесторов и кредиторов, а также из значения внутреннего аудита как основного элемента корпоративного управления. Автор констатировал, что на данный момент отсутствуют исследования, касающиеся нынешней ситуации и роли внутреннего аудита в корпоративном секторе страны. Поэтому автор предложил провести анализ деятельности подразделений внутреннего аудита в указанном секторе. Для этого были установлены соответствующие направления исследований, одна из которых-изучение качественных характеристик подразделений внутреннего аудита. В связи с этим, целью исследования является изучение качественных характеристик подразделений внутреннего аудита в корпоративном секторе Республики Молдова. Для достижения этой цели, автором была использована методика опроса, разработаны анкеты, соответствующие области исследований, которые впоследствии были переданы руководителям подразделений внутреннего аудита корпоративного сектора через электронную почту. Информация, содержащаяся в вопросниках, представляет собой период 2019 года. Основные результаты исследования показывают, что основными функциональными задачами внутреннего аудита являются классические задачи, такие как оценка безопасности и эффективности внутреннего контроля; мониторинг процесса ликвидации слабых мест системы внутреннего контроля; разработка рекомендаций по улучшению системы внутреннего контроля. Было отмечено несоблюдение положений ISPPIA. Наиболее важными факторами, влияющими на деятельность подразделений внутреннего аудита, являются недостаточное их обеспечение сотрудниками и продолжительность получения необходимой информации. Было выявлено, что в анализируемых экономических субъектах не проводится и не запланированы независимые внешние оценки, что доказывает несоблюдение ISPPIA из-за отсутствия необходимости такой оценки и относительно короткого периода деятельности подразделений внутреннего аудита.

Ключевые слова: внутренний аудит, корпоративный сектор, качественные характеристики, подразделение внутреннего аудита, исследовательские анкеты, исследование в aydume.

\section{INTRODUCTION}

The implementation of the Republic of Moldova - European Union (EU) Association Agreement and the intensification of market economy relations drives the reformation and modernization of the financial control system in our country, including the internal audit. Currently, many managers of economic entities are aware that internal audit is of significant importance and is an important and essential element in their economic management. Internal audit aims to provide managers with insurance and consultancy in order to achieve its objectives, offering recommendations for enhancing the effectiveness of the activity's result.

The importance of the research carried out in this field is conditioned by the implementation in our country of the Internal Public Financial Control, the model of which is elaborated by the European Commission, being part of the Acquis Communautaire and is to be transposed into the legal framework of all the new EU member states; also by developing a series of normative acts that regulate the internal audit of the public sector, which provide a wide spectrum of strict requirements regarding its exercise.

The increase of interest in the implementation of internal audit in the Republic of Moldova's corporate sector is conditioned by a number of factors, among which we can highlight the following: internal audit is an accessible resource, albeit underappreciated, the use of which contributes to increasing the efficiency of the entity; the big corporate scandals, which covered the United States of America and Europe (including the Republic of Moldova), have demonstrated the failures in the functioning of the external audit, the consequences of which can be the bankruptcy of the big companies; the internal audit became attractive for the owners of companioes, who entrusted the management of the entities of the professional managers; the establishment of an effective corporate governance within the entity, the internal audit being an indispensable element of it, is a positive signal for the potential investors and creditors of the entity.

Currently, the internal auditors in the corporate sector are facing the problems of organizing and functioning of the internal audit, because these aspects are not sufficiently regulated under the normative aspect or provided in the decisions of the professional bodies, as practiced in other states. We consider

December No. 2/2020 
that, the circumstances set out above confirm the actuality and importance of the research topic.

One of the basic objectives of the research conducted by the author in the field of internal audit, is the complex examination of the activity of internal audit subdivisions (IAS) in the corporate sector of the Republic of Moldova. The research directions have been established by the author, which in our opinion are relevant for investigating the current situation of internal audit in the country's corporate sector. These include:

1. The qualitative characteristics of the internal audit subdivisions.

2. Human resources management.

3. Operational activity.

In this article the author focuses on presenting the first established research direction, such as, the analysis of the qualitative characteristics of the internal audit subdivisions.

The research hypothesis is based on the need to examine the qualitative characteristics of the internal audit subdivisions, which contributes to the understanding of the current situation of the activity of the internal audit subdivisions in the corporate sector of the country.

\section{LITERATURE REVIEW}

It is necessary to mention that appropriate studies are needed to highlight the problematic aspects in the organization and functioning of the internal audit in the nominated sector, also to elucidate the perspectives in its development. In this context, after researching the native specialized literature, the author has found that, currently, there are no empirical studies regarding the current situation and the role of the internal audit in the corporate sector.

In particular, the aspects studied by local authors refer to the internal public audit. Thus, the results of the research conducted by Cauş L. [Caus, 2008:235-238], [Caus, 2011:196-200] refer to the particularities of the implementation and regulation of internal audit in the public sector of the country, as well as to the elucidation of the planning stage of the internal audit missions. In his papers, author Iachimovchi A. [Iachimovshi, 2010:167-171], [Iachimovshi, 2009:335-339] presents the basic methodological aspects of internal audit planning and monitoring the quality of audit work. Author Ratcov M. [Ratcov, 2008:244-246], [Ratcov 2008:258-260] reports on some theoretical aspects of internal audit, such as its role, functions, timeliness and perspectives. In these circumstances, we aim to fill the "gap" created in the local literature and to deepen the internal audit research in the corporate sector of the country through the present analysis.

At the same time, we must note that at the global level there are various studies conducted by international prestigious bodies related to internal audit. Thus, the Institute of Internal Auditors periodically (once in five years) conducts the study "Common Body of Knowledge on Internal Audit at a Global Level" (Common Body of Knowledge, CBOK) [7], with the primary objective of obtaining information concerning internal audit practices worldwide. At the same time, the collected data are the basis of the empirical studies in the field. Analysing the content of the nominated study we find that the Republic of Moldova was not included in the studies performed in the field of internal audit.

Also, important research in the field can be found in the specialized literature from Romania - an EU member state. In this context, we can mention the work of researcher Sima A. [Sima, 2010:16-25], the results of which show that in organizations that have developed an internal audit function, the process of alignment with the International Internal Auditing Standards of the Institute of Internal Auditors, it is either fully implemented or is in the process of implementation. Relevant information is provided by another study in the field [Precob, Rusu-Buruiana, 2015:13-21], carried out by Precob C. and Rusu-Buruiana A. The results of the research carried out show that the evaluation of the risks of the audited company is the main criterion used by the internal auditors in the planning of their activity, and the biggest weight in the totality of the activities of the internal auditors includes the monitoring and evaluation of the risks, followed by the verification of the accounting processes and the preparation of financial statements.

The most recent research developed in Romania was carried out by the KPMG international audit company. Entities from different sectors of activity were included in the study. The research highlighted the aspects related to the challenges of internal audit, among which the main ones were determined: effectiveness of the risk management program, availability of employees' skills, complexity and 
uncertainty of regulations, strengthening corporate governance and strategic processes [10].

At the same time, it is necessary to mention the advanced studies in the field of internal audit from the Russian Federation. Thus, the Institute of Internal Auditors in this country conducts research every two years on the current situation and the trends of developing the internal audit. The latest research was conducted jointly with KPMG in 2018 [11].

The results of the study show that the functional attributions at the present time of the internal audit subdivisions of the companies in the given country consist in evaluating the safety and effectiveness of the internal control system and consulting the management on various questions, and in the trends of the evolution of the internal audit the risk management evaluation is outlined.

Data sources and methods used. In this context, initially, in this paper we proposed to investigate the areas of internal audit, i.e. the entities that include its scope. This fact allows us to identify the prospects for the functioning of the internal audit.

The quantitative analysis of the data related to the entities registered in the Republic of Moldova presents the following results (table 1 and figure 1).

Information related to the registration of entities in the Republic of Moldova

\begin{tabular}{|l|l|c|}
\hline Nr. & \multicolumn{1}{|c|}{ The name } & \multicolumn{1}{|c|}{$\begin{array}{c}\text { Number at } \\
\mathbf{0 1 . 1 2 . 2 0 1 9}\end{array}$} \\
\hline 1 & \multicolumn{1}{|c|}{2} & 3 \\
\hline 1 & Limited Liability Companies & 87182 \\
\hline 2 & Individual entrepreneurs & 28255 \\
\hline 3 & Joint stock companies & 2372 \\
\hline 4 & Cooperatives (production, consumption, entrepreneur) & 2338 \\
\hline 5 & State and municipal enterprises & 1602 \\
\hline 6 & Non-commercial organizations & 464 \\
\hline 7 & Other & 1254 \\
\hline
\end{tabular}

Source: Developed by the author based on data from P. E. "Public Services Agency" [12].

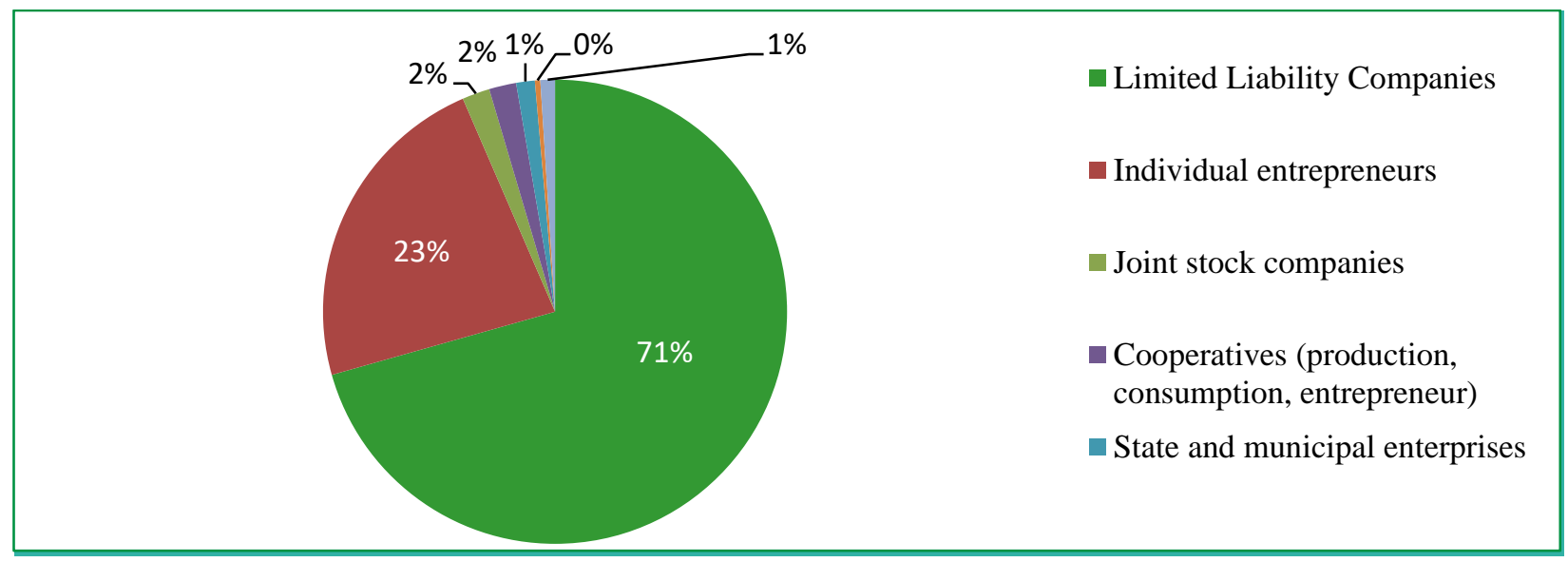

Figure 1. The structure of the entities that are registered in the territory of the Republic of Moldova, according to the legal forms of organization

Source: Developed by the author based on data from P.E. "Public Services Agency" [12].

We must mention that the internal audit is current for public interest entities. In accordance with the Law on Accounting and Financial Reporting [13], a public interest entity represents the entity the securities of which are admitted to a regulated market; the bank; insurer (reinsurer)/insurance company; body for collective investment in securities with legal personality; large entity that is a state-owned enterprise or a joint stock company in which the share of the state exceeds $50 \%$ of the share capital.

The quantitative analysis of the data related to the public interest entities registered in the Republic of Moldova presents the following results (figure 2). 


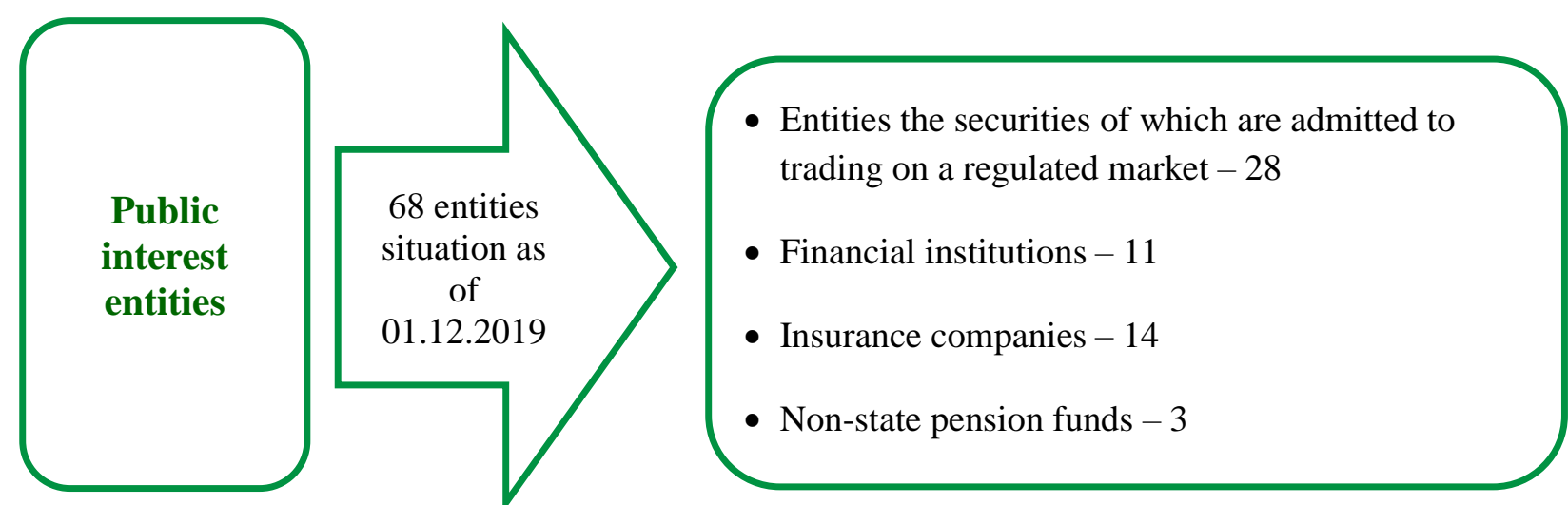

Figure 2. Information related to the registration of public interest entities as of 01.12.2019 Source: Developed by the author based on the data of the National Commission of the Financial Market (CNPF) [14].

Public interest entities, apart from non-state pension funds, have the organizational-legal form of a joint stock company. According to the information presented in table 1, there are currently 2372 joint stock companies, which form the basis of the corporate sector in the Republic of Moldova.

It is necessary to note that the present research was conducted using the qualitative research method, such as the semi-structured interview. For this purpose, the author developed questionnaires corresponding to the established research direction, which were submitted for completion to the heads of internal audit subdivisions of 20 entities in the corporate sector, operating in the financial-banking and financial-non-banking fields of the country. The information obtained through the questionnaires represents the October-December 2019 period.

Through the study, we aimed to identify and analyze the qualitative characteristics of the internal audit subdivisions. At the same time, the basic objective is to determine the compliance of the internal audit subdivisions with international advanced practices and the provisions stipulated by ISPPIA, in particular we consider ISPPIA 1300 "Quality Assurance and Improvement Program", ISPPIA 1310 "Requirements of the Quality Assurance and Improvement Program", ISPPIA 1311 "Internal Assessments", ISPPIA 1312 "External Assessments" and ISPPIA 1320 "Reporting on the Quality Assurance and Improvement Program" [15].

The analysis of the qualitative characteristics of the internal audit subdivisions covers the aspects related to:

- identifying the structures that fulfil the function of the internal audit and determining their age;

- establishing the attributions and functional subordination of the internal audit subdivisions;

- identification of the basic users of the internal audit subdivisions;

- assessing the degree of independence of the internal audit subdivisions from the management of the entity and the support from the board of directors;

- specifying the factors that influence the activity of the internal audit subdivisions;

- establishing the aspects related to the evaluations of the activity of the internal audit subdivisions and identifying evaluation indicators;

- assessing the degree of satisfaction of the head of the internal audit subdivisions with the results of the activity.

\section{RESEARCH RESULTS AND DISCUSSIONS}

The processing and analysis of the data obtained from the interviewed entities denote the following aspects of the internal audit activity. According to the "Qualitative characteristics of the internal audit subdivisions" research direction, structures that fulfil the function of internal audit were studied. Thus, in all the interviewed entities the function of the internal audit is performed by a distinct structure. This fact is appreciated positively and indicates a clear separation of the nominated function within the entities and, accordingly, the distribution of internal audit tasks. 
Regarding the age of the internal audit subdivisions, we note that it is relatively young - in most entities the internal audit operates from 1 year to 5 years. In this context, it should be mentioned that globally and in Europe, the position is significantly older, with around $25 \%$ of companies having organized the position for over 25 years [Chersan, 2016].

Another important aspect of the research is the determination of the basic functional attributions of the internal audit. Among the basic functional tasks of the internal audit are the evaluation of the safety and effectiveness of the internal control; monitoring the process of liquidation of the weaknesses of the internal control system; elaboration of recommendations for improving the internal control system; management assistance in developing the internal control system and advising on various questions. At the same time, we see that in most of the entities subjected to the study the internal audit does not carry out the evaluation of the corporate governance and the effectiveness of the risk management system. This aspect proves non-compliance with the ISPPIA 2110 "Governance" and ISPPIA 2120 "Risk management" [15], which provide that the internal audit activity must evaluate and contribute to the improvement of governance processes and risk management, using a systematic and methodical risk-based approach.

In our opinion, an important aspect in the organization of the internal audit function is the positioning of the internal audit subdivisions in the management hierarchy of the entity. Practitioners in the field of internal audit [Kryškin, 2017] consider that one of the main factors behind establishing the positioning of the internal audit subdivisions is the level of subordination. One of the main possibilities outlined at the moment is the functional subordination to the board of directors/the audit committee. This form is received as a classic and is predominantly used by high-level corporate governance entities. For example, in the Russian Federation this variant is especially prevalent in companies that are included in the top 200 of the most developed entities. It is considered that this ensures maximum independence of the internal audit unit, despite the fact that the tasks of the audit committee are the establishment of the priorities in the activity of the internal auditors, as well as the approval of the budget and the remuneration of the head of the internal audit structure.

The results of the study present data on the functional subordination of the internal audit subdivisions in the corporate sector to the board of directors/audit committee, which is in accordance with the ISPPIA 1100 "Independence and objectivity", ISPPIA 1110 "Organizational independence" and the best international practices [15].

The author considers that the use of this possibility in the conditions of the economic entities in the corporate sector of the Republic of Moldova implies some difficulties, such as:

- for the local entities, the audit committee represents a new concept, which is not fully implemented in the practice of entities in both the corporate and public sectors;

- the tasks of the audit committee (provided in the Law on the audit of financial statements [18] do not include aspects related to establishing the remuneration of the head of the internal audit structure;

- the level of qualification of the members of the audit committee and their lack of experience do not allow to set clear objectives for the activity of the internal audit structure;

- performing the specific functions of the audit committee by the general manager of the entity.

Another question, to which we wanted to get an answer, represents the identification of the basic users of the results of the internal audit subdivisions. Thus, the core users of the results of the internal audit subdivisions in all the analyzed entities are the board of directors/audit committee and the senior executive management. Also, most of the entities included in the study indicate linear management and external audit among users. At the same time, the entities representing financial institutions also mention users such as the National Bank of Moldova and the National Commission of the Financial Market.

Aditionally beneficial is the aspect that absolutely all entities report a high degree of independence from the management of the entity and also a maximum support from the board of directors/audit committee.

The analysis of the results of the study identified the factors that influence the activity of the internal audit subdivisions. In most of these entities they include: insufficient provision of the internal audit subdivisions with employees and the long time to obtain the necessary information, and the financial institutions additionally mention the factor - unplanned audit missions, which were not included in the annual audit plan. 
As we know, requirement to perform evaluations of both internal and external audit activity is found among the basic provisions of ISPPIA, in particular ISPPIA 1311 "Internal assessments" and ISPPIA 1312 "External Assessments". Analyzing the information related to the performance of internal audit assessments, we see that, in the entities included in the study, external evaluations are not performed and are not planned. At the same time, the research highlights the causes of not conducting independent evaluations. These include the lack of need for such an assessment and the relatively short period of activity of the internal audit subdivisions.

At the same time internationally, for example, in Romania the independent evaluation of the internal audit activity is performed in 58\% of entities [16]; and in the Russian Federation - in every fifth entity, included in the study [11].

Regarding the current evaluation of the quality of the activity of the internal audit subdivisions, we notice that it is performed in absolutely all the interviewed entities, which is appreciated positively.

Identification of indicators for evaluating the internal audit activity is of particular interest for research. In most entities these include: the level of fulfilment of the audit missions plan; the level of implementation of the recommendations, obtained from carrying out the audit missions and the results of the interview of the members of the board of directors/the audit committee. And the fourth entity included in the study mentions the following among the evaluation indicators: the number of risks eliminated/mitigated following the implementation of the recommendations; deviations from the audit mission plan (by time and resources) and the results of the interview of the audited structures.

And the level of satisfaction of the internal audit subdivisions' director with respect to the results of the activity of the given subdivisions is maximal in most of entities, while the fourth part of the entities considers it partially, taking into account the fact that there are always things to improve.

CONCLUSIONS

Currently, the existing research in the field of internal audit in the Republic of Moldova refers to the public sector of the country. We mention that the present research is the first empirical study of the current situation of internal audit in the corporate sector of the Republic of Moldova. One of the research directions established by the author is elucidated - the analysis of the qualitative characteristics of the internal audit subdivisions. We find that, at the present time, there is an increase of interest in the implementation of internal audit in the corporate sector through the awareness of the fact that it is significant and represents a basic element in the management of economic entities.

The research results denote the scope of the internal audit. This is represented by the joint stock companies, which form the basis of the country's corporate sector. The internal audit is actual for public interest entities, despite their importance to the public.

The main conclusions that were made following the study undertaken by the author on the qualitative characteristics of the internal audit subdivisions in the corporate sector of the Republic of Moldova, include the following aspects:

1. The internal audit function in the economic entities from the country's sector is relatively young, in most of the internal audit subdivisions entities it operates from 1 to 5 years. At the same time, it should be mentioned that globally and in Europe, the position is significantly older, around $25 \%$ of companies having organized the position for over 25 years.

2. We positively appreciate the fact that in all entities the internal audit function is performed by a distinct structure within them, which contributes to the clear separation of the responsibilities of the internal audit.

3. Among the basic functional tasks of the internal audit are its classical tasks, such as the evaluation of the safety and effectiveness of the internal control; monitoring the process of liquidation of the weaknesses of the internal control system; development of recommendations for improving the internal control system. In the same type, we observe a non-compliance with the provisions of ISPPIA 2110 "Governance" and ISPPIA 2120 "Risk management", which stipulate that the internal audit activity must evaluate and contribute to the improvement of the governance processes and risk management, using a systematic and methodical risk-based approach.

4. The study highlighted the factors that most influence the activity of the internal audit 
subdivisions. Among them we can mention the insufficient insurance of this with employees and the length of time for obtaining the necessary information.

5. Another negative aspect, which was identified as a result of the study, is that in the analysed economic entities independent external evaluations are not performed and planned, which proves non-compliance with ISPPIA 1300 "Quality Assurance and Improvement Program", ISPPIA 1310 "Requirements of the Quality Assurance and Improvement Program", ISPPIA 1312 "External Assessments" and ISPPIA 1320 "Reporting on the Quality Assurance and Improvement Program". The entities motivate this by the lack of the need for such an evaluation and the relatively short period of activity of internal audit subdivisions.

At the same time, at the international level, the independent evaluation is given more attention, for example, in Romania the independent evaluation of the internal audit activity is performed in 58\% of the entities; and in the Russian Federation - in every fifth entity.

\section{REFERENCES}

1. CAUȘ, L. Implementarea şi reglementarea auditului intern în Republica Moldova. In: Competitivitate și inovație în economia cunoașterii: probleme și soluții pentru România și Republica Moldova: conferința științifică internațională, 26-27 septembrie 2008. Chișinău: ASEM, 2008, vol. 2, pp. 235-238. ISBN 978-9975-75-440-8, ISBN 978-9975-75-443-9.

2. CAUȘ, L., POPOVICI, A. Planificarea misiunilor de audit intern. In: Analele Academiei de Studii Economice. Ediția a IX-a. Chișinău: ASEM, 2011, pp. 190-194. ISBN 978-9975-75-567-2.

3. IACHIMOVSCHI, A. Aspecte metodologice de planificare a auditului intern. In: Premisele dezvoltării economiei naționale în contextual crizei economice: conferința științifico-practică internațională, 28-29 mai 2010. Universitatea de Stat "Alecu Russo". Bălți, 2010, pp. 167-171. ISBN 978-9975-50-022-7.

4. IACHIMOVSCHI, A. Monitorizarea calităţii lucrărilor de audit. In: Competitivitatea și Inovarea în economia cunoașterii: conferința științifică internațională, 25-26 septembrie 2009. Academia de Studii Economice din Moldova. Chișinău: ASEM, 2009, vol. 2, pp. 335-339. ISBN 978-9975-75488-0.

5. RATCOV, M. Auditul intern - Actualitate şi perspective. In: Creșterea competitivității și dezvoltarea economiei bazate pe cunoaștere: conferința științifică internațională, 28-29 septembrie 2007. Academia de studii Economice din Moldova. Chișinău: ASEM, 2008, vol. 2, pp. 244-246. ISBN 978-9975-75-401-9.

6. RATCOV, M. Rolul şi funcţiile auditului intern. In: Competitivitate și inovație în economia cunoașterii: probleme și soluții pentru România și Republica Moldova: conferința științifică internațională, 26-27 septembrie 2008. Chișinău: ASEM, 2008, vol. 2, pp. 258-260. ISBN 9789975-75-440-8, ISBN 978-9975-75-443-9.

7. THE INSTITUTE OF INTERNET AUDITORS. Common Body of Knowledge (CBOK) [cited 19 december 2019]. Available: https://global.theiia.org/iiarf/Pages/Common-Body-of-KnowledgeCBOK.aspx

8. SIMA, A. Studiu privind perspectivele auditului intern = Study regarding the perspectives for the internal audit. In: Audit financiar. 2010, vol. 8, nr. 10, pp. 16-26. ISSN 1844-8801 [cited 01 january 2020]. Available: http://revista.cafr.ro/RevistaDetalii_RO?Cod=13

9. PRECOB, C., RUSU-BURUIANĂ, A. Caracteristicile auditului intern din România. Studiu privind percepţia auditorilor interni. In: Audit financiar. 2015, vol. 13, nr. 9 (129), pp. 13-21. ISSN 18448801 [cited 29 november 2019]. Available: http://revista.cafr.ro/RevistaDetalii_RO?Cod=146

10. KPMG. Auditul intern în era transformării continue. Sondaj de opinie a auditorilor interni din România. 2019, aprilie [cited 11 april 2019]. Available:

https://assets.kpmg/content/dam/kpmg/ro/pdf/2019/Sondaj-auditoriinterni_Romania_aprilie_2019.pdf

11. INSTITUT VNUTRENNIH AUDITOROV. Issledovanie tecuŝego sostoâniâ i tendentij razvitiâ vnutrennego audita v Rossii. 2017. 36 p. [cited 12 august 2019]. Available: https://www.iiaru.ru/contact/S_IA\%20rus\%20FIN.pdf

12. AGENTTIA SERVICII PUBLICE. Statistica [cited 01 january 2020]. Available: 
http://www.asp.gov.md/ro

13. Legea contabilității și raportării financiare: nr. 287 din 15.12.2017. In: Monitorul Oficial al Republicii Moldova. 2017, nr. 1-6, pp. 47-56 [cited 23 october 2019]. Available: https://www.legis.md/cautare/getResults?doc_id=120938\&lang=ro

14. COMISIA NAȚIONALA A PIEȚEI FINANCIARE. Informații statistice și analitice [cited 01 january 2020]. Available: www.cnpf.md

15. INSTITUTUL AUDITORILOR INTERNI. Standardele Internaţionale pentru Practica Profesională a Auditului Intern (Standardele de Audit Intern). 2016. 36 p. [cited 19 december 2019]. Available: https://na.theiia.org/translations/PublicDocuments/IPPF-Standards-2017-Romanian.pdf

16. CHERSAN, I.C. Studiu privind practici și tendințe în auditul intern în România și în lume. In: Audit financiar. 2016, vol. 14, nr. 9 (141), pp. 929-945. ISSN 1583-5812, ISSN on-line 1844-8801 [cited 17 november 2019]. Available: http://revista.cafr.ro/RevistaDetalii_RO?Cod=1072

17. KRYŠKIN, O. Nastol'naâ kniga po vnutrennemu auditu. Riski i biznes-processy. Moskva: Alpina Digital, 2017. 478 s. ISBN 978-5-9614-4449-0 [cited 29 february 2020]. Available: http://www.bibliorossica.com/book.html?currBookId=25531

18. Legea privind auditul situațiilor financiare: nr. 271 din 15.12.2017. In: Monitorul Oficial al Republicii Moldova. 2018, nr. 7-17, pp. 75-84 [cited 15 october 2019]. Available: https://www.legis.md/cautare/getResults?doc_id=110387\&lang=ro

\section{ARTICLE HISTORY}

Received 04 February 2020

Accepted 19 August 2020 